\title{
Fine Needle Aspiration Cytology Findings of Breast Lesions in Western Region of Nepal
}

\author{
Ghimire $P G^{1}$, Ghimire $P^{2}$, Gupta $S^{3}$
}

\begin{abstract}
Aim: Breast cancer is the most common neoplasm worldwide. Fine needle aspiration cytology is a minimally invasive, highly sensitive and cost effective investigation for breast lesions. The aim of our study was to evaluate the spectrum of fine needle aspiration cytology findings of breast lesions. Material and Methods: It was a prospective study conducted in the Department of Pathology during a 2 year period from Jun 2016- May 2018. A total of 284 patients with breast lesions were subjected to ultrasound guided fine needle aspiration cytology. Result: The age of presentation ranged from 13 years to 81 years with a mean age of $34.9 \pm 13.5$ years. Most common age group for breast lesions was in 21-30 age groups (39.1\%). Fibroadenoma was the most common benign pathology (26.8\%) followed by fibrocystic changes (26.4\%). Malignancy was noted in $16.2 \%$ with majority in the $41-50$ age groups. Parasitic infection was noted in 2 cases. Conclusion: Screening of breast lesions is warranted resulting in significant reduction of morbidity and mortality related to breast cancers. Fine needle cytology plays a pivotal role in the overall management of breast lesions.
\end{abstract}

Key words: Fine needle aspiration, breast, carcinoma, fibroadenoma

\section{INTRODUCTION}

Breast lumps are common surgical problems in the day to day surgical practice. Although, imaging investigations can be helpful in characterizing most of the lesions, a cytological or pathological diagnosis is detrimental not only to confirm those findings but also in equivocal cases. Fine needle aspiration cytology (FNAC) has emerged as an investigation of choice in many institutions due to its relative minimally invasive nature. Furthermore, image guided FNAC has proved to result in greater diagnostic value thus decreasing the overall morbidity. In this study, we evaluated the spectrum of breast lesions commonly encountered on ultrasound guided FNAC, its efficacy and histopathological correlation.

\section{MATERIALAND METHOD}

It was a prospective study performed on patients who had presented with breast lump and referred to the Department of Pathology for Fine needle aspiration cytology. FNAC was done under ultrasound guidance using General Electric Logiq P5 ultrasound with high frequency linear array transducer. FNAC was performed by a single pathologist using a 24 Gauze needle. Skin is properly disinfected, the needle is introduced into the lesion, and several passes are made through the lesion prior aspiration. After aspiration, the sample were spread on a glass

1. Dr. Pragya Gautam Ghimire

2. Dr. Prasanna Ghimire

3. Dr. Sharmila Gupta

Address for correspondence:

Dr. Pragya Gautam Ghimire

Department of Pathology

Nepalgunj Medical College \& Teaching Hospital

Kohalpur, Banke

Email: drpragya@gmail.com slide and allowed to air dry following which staining was done with Giemsa stain. Staining with ZiehINeelsen was performed on visualization of epithelioid granulomas, multinucleated giants cells and areas of necrosis for further confirmation of acid fast bacilli. In cases of inadequate sampling, a repeat aspiration was performed preferentially from another site. Unsatisfactory and suspicious smears were excluded from the study.

\section{RESULT}

The age of the patients ranged from 13 years to 81 years with a mean age of $34.9 \pm 13.5$ years. Majority of the cases were females 272 (95.8\%), with only $12(4.2 \%)$ male patients. The most common age group for the lesions was in the $21-30$ years age group (Table I).

\begin{tabular}{|c|c|c|}
\hline $\begin{array}{c}\text { Age group } \\
\text { (years) }\end{array}$ & Frequency & $\begin{array}{c}\text { Percentage } \\
\%\end{array}$ \\
\hline $11-20$ & 20 & 7.0 \\
\hline $21-30$ & 111 & 39.1 \\
\hline $31-40$ & 81 & 28.5 \\
\hline $41-50$ & 43 & 15.1 \\
\hline $51-60$ & 11 & 3.9 \\
\hline $61-70$ & 9 & 3.2 \\
\hline $71-80$ & 7 & 2.5 \\
\hline $81-90$ & 2 & 0.7 \\
\hline Total & 284 & $100 \%$ \\
\hline
\end{tabular}

Table I: Distribution of patients according to age group

Breast lump was the most common presenting complaint in 228 cases $(80.3 \%)$. The clinical presentation of breast lesions is tabulated in Table II. Bilaterality of lesions was noted in 32 cases 
(11.3\% cases). Benign lesions including miscellaneous constituted $83.8 \%$ of cases. Most common benign pathology was fibroadenoma (26.8\% of cases) followed by fibrocystic changes (26.4\%). There were 46 malignant lesions (16.2\% of total cases). All malignant lesions were invasive ductal carcinoma except one case of medullary carcinoma and two cases of malignant phyllodes. The relative frequency of the cytological diagnosis is tabulated in Table III. Among male patients, gynaecomastia was the most common findings noted in 7 cases. There was no significance between cytological diagnosis and age group, with $p$ value of 0.07 .

\begin{tabular}{|l|c|c|}
\hline $\begin{array}{l}\text { Presenting } \\
\text { Complaint }\end{array}$ & Frequency & $\begin{array}{c}\text { Percentage } \\
\%\end{array}$ \\
\hline Lump & 228 & 80.3 \\
\hline Pain & 6 & 2.1 \\
\hline Lump and pain & 46 & 16.2 \\
\hline Nipple discharge & 3 & 1.1 \\
\hline Breast enlargement & 1 & 0.4 \\
\hline Total & 284 & 100.0 \\
\hline
\end{tabular}

Table II: Relative frequency of presenting complaints

\begin{tabular}{|l|c|c|}
\hline Pathologies & Frequency & Percentage \\
\hline Gynaecomastia & 7 & 58.3 \\
\hline Carcinoma & 3 & 25.0 \\
\hline Fibroadenoma & 1 & 8.3 \\
\hline Miscellaneous & 1 & 8.3 \\
\hline Total & 12 & 100.0 \\
\hline
\end{tabular}

Table IV: Relative frequency of male breast pathologies

\section{DISCUSSION}

Breast carcinoma is the most common malignancy in woman worldwide accounting for almost $25.1 \%$ of all cancers. ${ }^{1}$ The international incidence of breast cancer is varied, with highest incidence in United States and Europe with lowest incidence in South Asia. Although the incidence of breast cancer is higher in developed countries, the mortality is greatest in developing countries due to less awareness and screening programs ${ }^{1}$. Breast cancer screening with triple assessment approach has significantly increased early detection of breast cancer and decreased overall morbidity and mortality ${ }^{2}$. Breast lump have a varied etiology and characterization of the lesions clinically has limitations warranting radiological and pathological correlation $^{3}$. Fine needle aspiration cytology has been initial investigation of choice for evaluation of breast lumps with high degree of accuracy ${ }^{4}$.

Although, core needle biopsy (CNB) is more sensitive than FNAC, the specificity is similar; thus in resource limited settings FNAC is the investigation of choice for evaluation of breast lesions.

\begin{tabular}{|c|c|c|c|c|c|c|c|c|c|c|}
\hline & \multicolumn{9}{|c|}{ AGE GROUP (in years) } & \multirow[b]{2}{*}{ Percentage } \\
\hline DIAGNOSIS & $11-20$ & $21-30$ & $31-40$ & $41-50$ & $51-60$ & $61-70$ & $71-80$ & $81-90$ & TOTAL & \\
\hline Fibroadenoma & 13 & 30 & 25 & 7 & 1 & 0 & 0 & 0 & 76 & 26.8 \\
\hline Fibrocystic disease & 3 & 33 & 29 & 8 & 0 & 2 & 0 & 0 & 75 & 26.4 \\
\hline Abscess & 1 & 13 & 5 & 4 & 2 & 1 & 0 & 0 & 26 & 9.2 \\
\hline Malignant tumors & 0 & 3 & 8 & 17 & 4 & 6 & 6 & 2 & 46 & 16.2 \\
\hline $\begin{array}{l}\text { Hypertrophic fat } / \\
\text { lipoma }\end{array}$ & 0 & 2 & 5 & 0 & 3 & 0 & 0 & 0 & 10 & 3.5 \\
\hline $\begin{array}{l}\text { Lactational } \\
\text { adenoma }\end{array}$ & 1 & 5 & 0 & 0 & 0 & 0 & 0 & 0 & 6 & 2.1 \\
\hline Galactocele & 0 & 7 & 0 & 0 & 0 & 0 & 0 & 0 & 7 & 2.5 \\
\hline Accessory breast & 0 & 3 & 2 & 0 & 0 & 0 & 0 & 0 & 5 & 1.8 \\
\hline Gynaecomastia & 1 & 4 & 0 & 2 & 0 & 0 & 0 & 0 & 7 & 2.5 \\
\hline Granulomatous & 0 & 4 & 2 & 0 & 0 & 0 & 0 & 0 & 6 & 2.1 \\
\hline Acute mastitis & 1 & 2 & 1 & 0 & 0 & 0 & 0 & 0 & 4 & 1.4 \\
\hline Miscellaneous & 0 & 2 & 2 & 2 & 1 & 0 & 1 & 0 & 8 & 2.8 \\
\hline Breast cyst & 0 & 0 & 0 & 1 & 0 & 0 & 0 & 0 & 1 & 0.4 \\
\hline $\begin{array}{l}\text { Cellular papillary } \\
\text { lesion }\end{array}$ & 0 & 0 & 0 & 2 & 0 & 0 & 0 & 0 & 2 & 0.7 \\
\hline $\begin{array}{l}\text { Non-Neoplasticl } \\
\text { Normal }\end{array}$ & 0 & 3 & 2 & 0 & 0 & 0 & 0 & 0 & 5 & 1.8 \\
\hline
\end{tabular}

Table III: Cross-tabulation of different pathologies on FNAC at different age groups (non- gender specific) 
Majority of our patients were in the 21-30 year age group (39.1\%) which in keeping with other studies. ${ }^{5}$. Multiple factors could be related to the increased incidence of the lesions at this age at our setup. Firstly, young females are recently more aware regarding breast disease; clinicians are concerned for a possible neoplastic entity. Moreover, early marriage and hormonal contraceptive use in this region could be another factor. This population mandates regular follow up albeit benign etiology. A limitation in our study however includes pertinent family history of patients were not sought in all cases.

Lump in isolation was the most common complaint for presentation $(80.3 \%)$ followed by pain. Nipple discharge was present in only 3 cases ( $1.1 \%$ of total cases). Left breast was involved in $52.1 \%$ of total cases. Laterality of lesions with preferentially left breast involvement have also been reported in other studies.

Majority of the FNAC diagnoses of breast lesions were benign with studies having a varied results ranging from $24 \%$ to $77.5 \%$. Among the breast lesions in our study, benign pathologies outnumbered malignant pathologies constituting $82.3 \%$ of the total caseswhich is higher than in keeping with studies by Panjvaniet al. ${ }^{7}$

Fibroadenomas are the most common benign breast tumors in women under 30 years of age and certain studies have demonstrated almost $68 \%$ of all breast lumps and $44 \%$ to $94 \%$ of biopsied breast lesions ${ }^{8}$. Fibroadenoma is the most common benign pathology in our study with a total 76 cases among which 12 cases were cellular/complex and 4 cases were fibroadenoma with lactational changes. In our study, most common age group for fibroadenoma was noted in 21- 30 age group which is similar to other studies.

Fibrocystic changes were the second most common finding noted in $26.4 \%$ of the cases. Studies by Godwins et al have also reported similar findings ${ }^{5}$. Various studies have demonstrated possible etio-pathogenetic relationship between fibrocystic disease and breast cancer ${ }^{9}$. A genetic-environmental interactions has been postulated for breast carcinoma and individuals with fibrocystic disease with positive family history have increased susceptibility to environmental factors ${ }^{10}$.

Malignant lesions which included carcinoma as well as malignant phyllodes was the third most common breast pathology group in our study accounting to 46 cases (16.2\%) with majority cases in female. In India, the female to male breast cancer incidence ratio has been estimated at $64: 3^{11}$. Majority of breast carcinomas are invasive ductal carcinoma approximately $70-80 \%$ of all. In our study, all malignant cases were invasive ductal carcinoma with a rare sub type of medullary carcinoma and two cases of malignant phyllodes.
Male breast carcinoma (MBC) constitutes less than $1 \%$ of all breast cancer. There is a geographical variation in the incidence rates of breast carcinoma with maximum incidence in $\mid s$ srael $^{11}$. Hormonal imbalance, radiation exposure, genetic susceptibility (mutation of the gene BRCA 2), alcoholism and family history of breast carcinoma are predisposing risk factors $^{12}$. Most breast cancers are ductal with only $10 \%$ as carcinoma in situ $^{13}$. There has been a dearth on the study of incidence of $\mathrm{MBC}$ in South Asia with few studies demonstrating variable incidence rate. Studies by Samantara et al have reported prevalence of male breast lump constituting $2.5 \%$ of all breast lumps and MBC accounted $1.34 \%$ of all breast cancer which is in our study ${ }^{14}$. Majority of breast lesions in male are benign with gynaecomastia as the most common cause ${ }^{11,12}$. In our study, of all the male breast lesions; gynaecomastia constituted majority (58.3\%) of the cases.

Parasitic infections are endemic in our regions; however their presentation as breast lump is rare with very few cases reported in the literature ${ }^{15,16}$. In our study, isolated breast cysticercosis and filariasis were noted in one case each. As imaging findings of parasitic infections of the breast are not well understood, either cases were clinically suspected of breast tumors, with imaging being inconclusive.

\section{CONCLUSION}

Our study demonstrated breast lesions at younger age group than other population. Identification of possible risk factors and screening at early age is warranted for decreasing morbidity and mortality. Besides, in endemic regions like ours; a high degree of suspicion for parasitic infection should be borne in mind and considered in the differential diagnosis of breast lumps. Fine needle aspiration cytology preferable image guided of breast lesion has significant yield in atypical and doubtful cases.

\section{REFERENCE}

1. Ghoncheh M, Pournamdar Z, Salehiniya H. Incidence and Mortality and Epidemiology of Breast Cancer in the World. Asian Pac J Cancer Prev. 2016;17(S3):43-6.

2. Kharkwal S, Sameer, Mukherjee A. Triple test in carcinoma breast. J Clin Diagn Res. 2014;8(10):NC09-11.

3. Rahman MZ, Sikder AM, Nabi SR. Diagnosis of breast lump by fine needle aspiration cytology and mammography. Mymensingh Med J. 2011;20(4):658-64.

4. Mendoza P, Lacambra M, Tan PH, Tse GM. Fine needle aspiration cytology of the breast: the nonmalignant categories. Patholog Res Int. 2011;2011:547580.

5. Godwins E, David D, Akeem J. Histopathologic analysis of benign breast diseases in Makurdi, North Central Nigeria. International Journal of Medicine and Medical Sciences. 2011;3(5):125-8.

6. Muddegowda PH, Lingegowda JB, Kurpad R, Konapur P, Shivarudrappa A, Subramaniam P. The value of systematic pattern analysis in FNAC of breast lesions: 225 cases with cytohistological correlation. J Cytol. 2011;28(1):13-9.

7. Panjvani SI, Parikh BJ, Parikh SB, Chaudhari BR, Patel KK, Gupta 
GS, et al. Utility of fine needle aspiration cytology in the evaluation of breast lesions. J Clin Diagn Res. 2013;7(12):2777-9.

8. Lee M, Soltanian HT. Breast fibroadenomas in adolescents: current perspectives. Adolesc Health Med Ther. 2015;6:159-63.

9. Georgescu T, Naftali Z, Simu G, Nistor V, Craciu C, Ilniczky P, et al. [Retrospective studies on the relation between fibrocystic disease and cancer of the breast with therapeutic conclusions]. Chirurgia (Bucur). 1992;41(1):10-8.

10. Petrakis NL. Genetic-environmental interactions in relation to low dose studies: a possible model from breast cancer. Environ Health Perspect. 1981;42:97-102.

11. Chandanwale SS, Gupta K, Dharwadkar AA, Pal S, Buch AC, Mishra N. Pattern of palpable breast lesions on fine needle aspiration: $A$ retrospective analysis of 902 cases. J Midlife Health. 2014;5(4):186-91.

12. Charlot M, Beatrix O, Chateau F, Dubuisson J, Golfier F, Valette PJ, et al. Pathologies of the male breast. Diagn Interv Imaging. 2013;94(1):26-37.

13. Fentiman IS, Fourquet A, Hortobagyi GN. Male breast cancer. Lancet. 2006;367(9510):595-604.

14. Samantara S, Panda S, Dash S, Samantaray S, Rout N. Clinicopathological study of male breast lesion: An experience in a regional cancer center, Odisha. International Journal of Medical Science and Public Health. 2017;6(8):1255-61.

15. Bhattacharjee HK, Ramman TR, Agarwal L, Nain M, Thomas S. Isolated cysticercosis of the breast masquerading as a breast tumour: report of a case and review of literature. Ann Trop Med Parasitol. 2011;105(6):455-61.

16. Sahai K, Kapila K, Verma K. Parasites in fine needle breast aspirates-assessment of host tissue response. Postgraduate Medical Journal. 2002;78(917):165-7. 